\title{
COREESPONIDENTEF.
}

\section{ELEVATION OF AMERICA IN THE TERTIARY PERIODS.}

Srr,--I notice in recent numbers of the Geologroal Magazine that Mr. Upham has been discussing his views on the elevation of the Gulf of Mexico, etc. It seems a pity that gentlemen, who desire to launch such startling hypotheses, should not devote more time to settling the facts upon which these hypotheses are based, before promulgating their new views. As the statements made by Mr. Upham may by many be taken as properly verified, and more confusion be thereby occasioned, permit me to call attention to a few facts which have been verified.

1. The late Dr. Maack when on the isthmus of Darien did not collect any Pleistocene fossils from the summit of the Atrato divide 763 feet above the sea. 2. The Pleistocene fossils collected by Dr. Maack were from an elevation of only 150 feet on the Panama side, ten miles from Panama city. The fossils above this height collected by Dr. Maack are Eocene or Miocene exclusively, and related to the Miocene fauna of Santo Domingo, as indeed was pointed out by Gabb nearly twenty years ago (Proc. Am. Phil. Soc. vol. xii. p. 572). 3. The summit or dividing ridge is not fossiliferous, and is probably not later than the Mesozoic epoch.

I may add, from information to be shortly published, that the supposed great elevation of Florida at any time since the later Eocene is as improbable as any hypothesis which could well be conceived. The conclusions which the facts necessitate in the case of Florida may be briefly outlined as follows:-During the later Eocene, west central Florida was an island, like one of the Bahamas at present, composed exclusively of organic marine sediments which in the Vicksburg epoch attained an unbroken thickness of more than 1000 feet. The whole submarine plateau above which the present Florida rises may turn out to be of this age and constitution. This island had a land-shell fauna derived from the south. The strait between the island and the main coast north of it was more than fifty miles wide at the narrowest point, and was only closed at the beginning of the Pliocene. There have been gentle changes of level since the Eocene, but nothing violent, and the vertical range has been small. 'The Eocene and the old Miocene faunas were of a subtropical character like the Antillean fauna at present. A change took place in Mid-Miocene by which a cool, temperate, or colder water fauna invaded the Floridian region from the north, and about 200 feet of strata (Chesapeake Group) were deposited; equivalent to the well-known Miocene beds of Virginia and Maryland. With the elevation which connected the Floridian islands with the continent a warmer era was again inaugurated in the sea, and an invasion of Pliocene Vertebrates began, on the Peninsula of Florida.

There were unquestionably great changes of level on the continent, increasing as one goes northward, both in Miocene and Pleistocene times. In the Antilles it has been proved that great changes have taken place. But the Floridian region, for some unknown reason, escaped, and Yucatan, probably, also. 
I have been making a special study of Floridian Geology for some years, and hope to publish a considerable amount of new information on that subject during the coming summer.

Smithsonian Institution, U.S. Nationai. Museum, Washington, April 15, 1891.

WM. H. DaLL.

THE GEOLOGY OF THE SALT RANGE OF THE PANJAB.

Srr,--In the latest number (part i. vol. xxiv.) of the Records of the Geological Survey of India there is an interesting paper by Mr. C. S. Middlemiss on the Geology of the Salt Range of the Panjab. Admirable sections are given illustrating two points until recently in dispute, the positions of the Conularia Bed and of the Obolus Shales; and a very bold beginning is made of a fresh discussion, regarding the age and mode of origin of the Salt Marl and its minerals, advocating peculiar eruptive conditions connected with a primitive and hitherto undisturbed subterranean magma. Until Mr. Middlemiss developes his position, it would be premature to comment thereon; I will only ask leave to correct two personal errors in the paper. On p. 25 a quotation is made from my paper on the geology of the Panjab, published in the Provincial Gazetteer, whereby I am made to appear as executing an erroneous reversal of opinion upon a disputed unconformity in the Salt Range. Mr. Middlemiss must have overlooked the note at the beginning of the section on the Salt Range, stating that "this sketch is by $\mathrm{Mr}$. Wynne." I did not alter a word of it. So the passage in question is a repetition by Mr. Wynne of a view against which I had remonstrated in vain. The other point is on $\mathrm{p} .20$, where $\mathrm{I}$ am represented as " not entirely agreeing" with the erroneous view of the Conularia horizon. It refers to a short paper in which I had endeavoured to soften a somewbat acrimonious dispute by an impartial summary of the evidence; but there can be no doubt as to which side my own opinion leaned. I even suggested the conclusion which Mr. Middlemiss now presents as established : regarding the "pebbles" with Conularia I asked-"Is it not more plausible to suppose that they were washed into the gravel bed from some conternporaneous (Palæozoic) pool deposit close by?" (Records, vol. xix. p. 133).

Clifton, 29th April, 1891.

H. B. Medicott.

\section{OPITUATEY.}

WE regret to record the death of Professor Joseph Leidy, the distinguished American physiologist and palæontologist. The deceased, who was in his sixty-eighth year, was Professor of Anatomy in the University of Pennsylvania, and of Natural History in Swarthmore College. He was also President of the Academy of Natural Sciences of Philadelphia, Director of the Department of Biology in the University, and a Foreign Member of the Geological Society of London. His more important contributions to scientific literature were, "The Extinct Mammalian Fauna of Dakota and Nebraska," and "Freshwater Rhizopods of North America." $\mathrm{He}$ also wrote an elementary treatise on human anatomy.-Standard, Friday, 1st May, 1891. 